\title{
2216 人形峠型ウラン鉱床に対する水力採鉱試験について
}

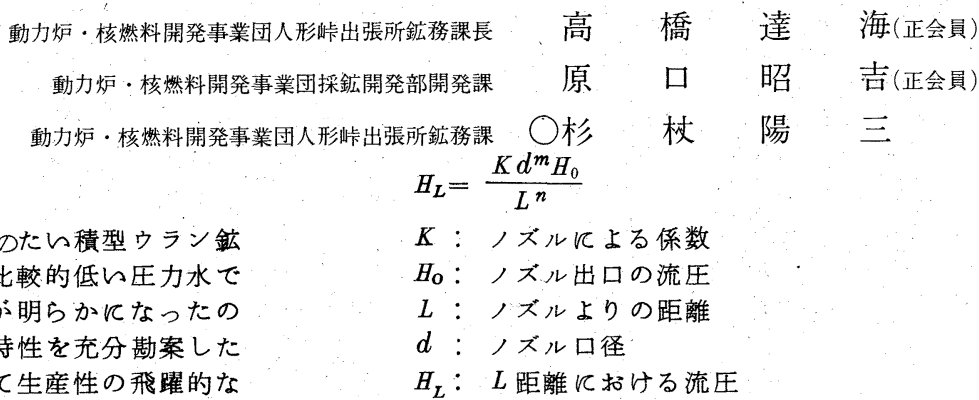
より $35 \mathrm{~kg} / \mathrm{cm}^{2}$ とした。高圧ポンプはモニタの掘さく能 力执よび鉱石, 水比から吐出量を $1.7 \mathrm{~m}^{3} / \mathrm{min}$ とし, 吐出 圧力はノズル元圧 $35 \mathrm{~kg} / \mathrm{cm}^{2}$ 管路抵抗 $1 \mathrm{~kg} / \mathrm{cm}^{2}$ を加 え安全率を見込み $40 \mathrm{~kg} / \mathrm{cm}^{2}$ とした。パルプ輸送はポン プ通過方式と押込み方式を検討した結果, 低揚程でよん こと, 設備費が安いこと,などからポンプ通過方式を採 用することとし, 輸送量 $2 \mathrm{~m}^{3} / \mathrm{min}$, 濃度 $20 \%$; 奏揚程 $15 \mathrm{~m}$, 最大輸送鉱石粒度 $30 \mathrm{~mm}$ を满たするのとした。

\section{4. 採鉱方法之試験采統}

鉱床は新第 3 紀の比較的新しh基底れさ岩扣よひ砂岩 互層で别離性に富み，下盤は風化した花こう岩である。 鉣石は人形石を主とする非酸化鉱とリン灰ウラン石を主 とする酸化鉱に大別される。水力採鉱の対象と考元てい る鉱床は非酸化鉱の5 万の比較的低品位の部分で微細な ウラン鉱物がれきの表面やれきとれきとの砂質膠結部に 主として賦存して打り，峠地区の非酸化鉱低品位部のれ き岩層の湿式ふるい分析の結果(第 1 図) てよってもウ ランは粒度の小さい部分に偏在していることが判明して

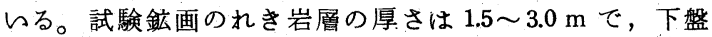
は北に向から約 2 度で傾斜している。地山比重は約 2 で あり，鉱石の比重は約 2.6 である。

\section{3. 試験設 備の 概 要}

掘さく所要王力は基礎試験で $7.5 \mathrm{~kg} / \mathrm{cm}^{2}$. 以上必要であ ることが明らかになったので安全率を見込み $10 \mathrm{~kg} / \mathrm{cm}^{2}$ とした。モ二タの掘さく能力は $10 \mathrm{~m}^{3} / \mathrm{h}$ とし, 有効掘さ く長を $6 \mathrm{~m}$ とした。また鉱石, 水比は水力採炭実績を参 考に検討の結果 1：10 とした。以上の諸条件からノズル 元圧は資源技術試験所で発表された中心流圧の実験式

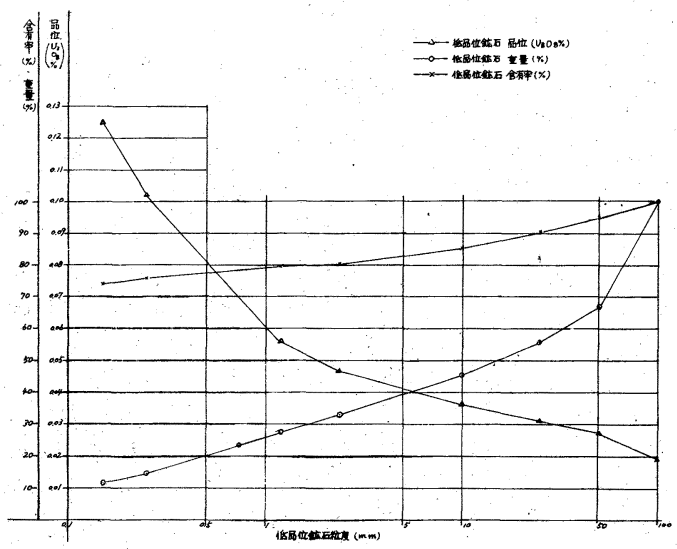

第1図拤地区非酸化带低品位釷石湿式子.るい分析結果

\section{1 採鉱法}

採鉱法で最も問題になった点は掘さくされた鉱石の流 送であった。水力採炭では柱房式切羽を採用してているが 当鉱山では（1）鉱床の傾斜が少ない，（2）比重が大きい, (3)大れさが存在する，とい5条件のため掘さくされた 鉱石の自然流送が不可能であるので長壁式切羽を設定し, 圧力水に上り掘さくと同時に押流しを行ならことにした。 また長壁式切羽のため支保など切羽内の作業が必要とな り採掘作業中も切羽内作業を行な5ため第 2 図のよ 5 亿

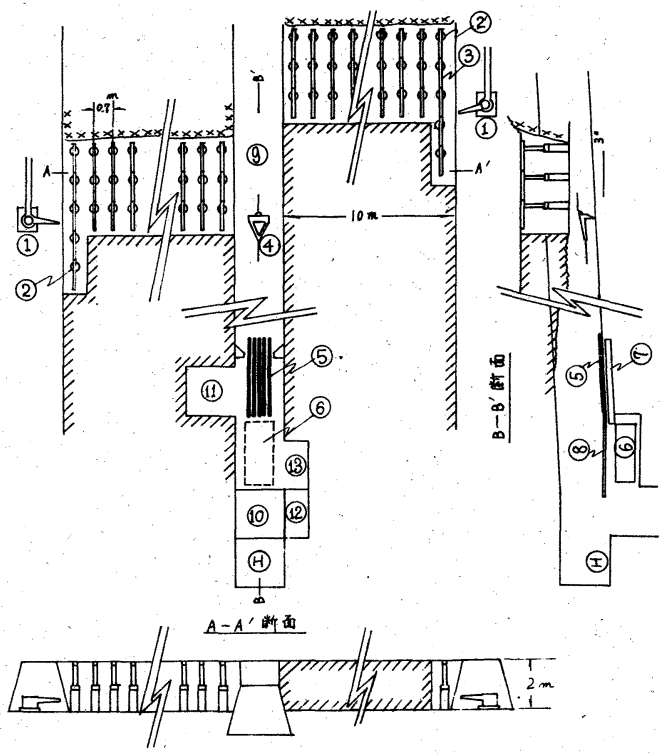
(1) 採鉱モニタ
(3) カッペ
(2) さつ鉄柱 (2) 水压鉄柱
(6) $10 \mathrm{~mm}$ 目共
(4)スクレー
(12) 人道
(10)捨石ビン
(8) $100 \mathrm{~m}$
(11) 板張
(13) 操作室 勇 $20 \mathrm{H}$ スクレーパホイスト
第2図切羽仕様

Vol. 84 No. 959 ('68-3) 
中割坑道の両側に切羽を設け掘さくと支

保を交互に行なった。

\section{$4 \cdot 2$ 試験系統}

試験系統で最も問題になった点は大れ きの処理方法であった。当初は採掘跡に 充てんまたは放置する予定であったが試 験の結果作業工程に組合わすことが困難 であるため搬出することにした。中割坑 道の運搬は当初は敷設勾配 5 度のトラフ に上る自然流送を計画したが大れきもす へて搬出することにしたためトラフによ る自然流送ができずスクレーパを採用し た。またスクレ一パの運搬距離に対する 欠点を補な5ために2 台直列飞使用した。 第 2 図の切羽仕様, 第 3 図の試験采統と もと 42 年度のものである。

\section{$4 \cdot 3$ 人員配置および作業順序}

人員配置は高厈ポンプ運転員 1 名，モ 二夕操作員 1 名, 跡処理員 3 名, (42 年 度は 2 名) スクレーパ運転員 1 名, 捨石 処理員 1 名, 輸送ポンプ運転員 1 名およ び蓄電池機関車運転員 1 名, 計 9 名とした。跡処理員と は立柱，抜柱执よび切羽肩部の先掘進を行なう作業員で ある。

作業順序は両翼切羽を各々のA，Bとすると

(1) A 切羽有部の掘さく。

(2) A 切羽掘さく跡の支保。

(3) A 切羽ほ 5 中央へモ二タ移設。

(4) A 切羽深部の掘さく。

(5) A 切羽深部の支保。

(6) B 切羽人モ二タ移設。

この間 B 切羽に扣いては掘さく準備，抜柱扣よび肩部 切込口の先進掘さく等を行ない，これらの作業を A， B

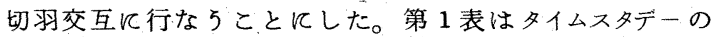
一例であり，グラフはモ二タ操作員につんてのものであ る。グラフ中(1)はA 切羽肩部, (2)はA 切羽梁部, (3)は $\mathrm{B}$ 切羽肩部, (4)は B 切羽有部, (5) B 切羽深部の掘さくで ある。

\section{$4 \cdot 4$ 支保}

人形峠型ウラン鉱床に水力採鉱法を適用した場合の最 大の欠点は飛散水で軟弱な天盤が洗掘され天井囲い作業 が困難になること扣よび飛散スライムが後方にたまり抜 柱作業が困難になることである。

\section{5. 掘さく}

掘さくは主に $22 \mathrm{~mm}$ 径のノズルを使用したが，この場 第1表タイムスタデー

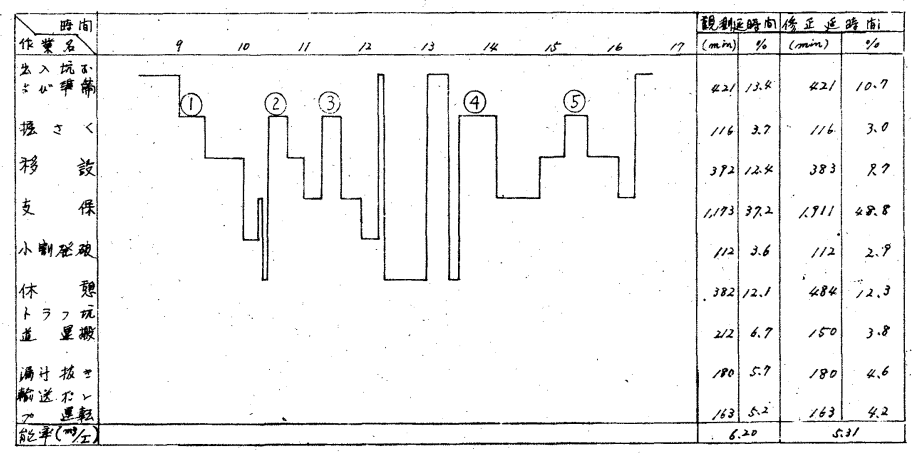

合の高压ポンプの吐出压力报よび吐出量はそれぞれ 39

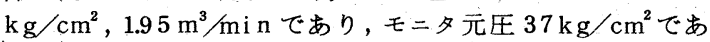
った。

$5 \cdot 1$ モニタの掘さく能力に関する諸条件

ノズルロから掘さく面までの距離と掘さく能力の関係 は岩石の性状により一定でないが，この鉱画での能率的 な掘さく限界距離は経験的に $6 \sim 7 \mathrm{~m}$ であり，この場合 の中心流圧は $18 \sim 16 \mathrm{~kg} / \mathrm{cm}^{2}$ である。れきの粒度分布と モ二タの掘さく能力の関係は大れきのかみ合い，あるい は存在位置により大きく左右され一定ではないが $1 \mathrm{~m}$ 大 の巨れさが存在すると掘さく能力は著しく低下し，小割 発破を必要とする。

\section{$5 \cdot 2$ モニタの掘さく能率}

モ二タの掘さく能力と鉱石, 水比は第 2 表のと打りと なった。年度により試験項目が異なり，モ二タの掘さく 能力はばらついているが能率を主目的とした 40 年度は 22 $\mathrm{mm}$ 径のノズルを使用した場合平均 $22.7 \mathrm{~m}^{3} / \mathrm{h}$ となった。 41 年度のモ二夕掘さく能率 $19.4 \mathrm{~m}^{3} / \mathrm{h}$ 亿対し鉱石, 水比 が 1：10.4 となっているのは共振ふるいおよび輸送ポン プの容量不足によるもので，掘さく押流しのみの場合は $1: 6$ である。噴射時間は掘さく時間と切羽内の押し流 し時間に分けられ，掘さく時間は噴射時間の 60〜70\% になっている。

\section{6. パイブ輸送}

言 1. 能率算出分母はモニタ操作員, 跡方処理員, ス クレーパ運転員, 捨石処理員, 輸送ポンプ運転 員までとした。

2. 能率算出分子は地山採掘量とした。

3. タイムスタデーは昭和 40 年 9 月 15 日に行なった ものでグラフはモニタ操作員の作業工程である。

4. 修正延時間 (1) は1サイクルの作業を完成させ るためと必要な時間を観測延時間より補正したも のである。 
第 2 表 $€=$ タ 9 生産性と原単位

\begin{tabular}{|c|c|c|c|c|c|c|c|c|}
\hline \multirow{2}{*}{ 年度 } & \multirow{2}{*}{$\begin{array}{l}\text { 掘さく量 } \\
\left(\mathrm{m}^{3}\right)\end{array}$} & \multicolumn{2}{|c|}{ モニタの掘さく能率 } & \multicolumn{2}{|c|}{ 力 量 } & \multirow{2}{*}{$\begin{array}{l}\text { 薬 } \\
\left(\mathrm{kg} / \mathrm{m}^{3}\right)\end{array}$} & \multirow{2}{*}{$\begin{array}{l}\text { 坑 木 } \\
\left(\mathrm{m}^{3} / \mathrm{m}^{3}\right)\end{array}$} & \multirow{2}{*}{ 備 } \\
\hline & & $\left(\mathrm{m}^{3} / \mathrm{m}^{3}\right)$ & $\left(\mathrm{m}^{3} / \mathrm{h}\right)$ & (1) $\left(\mathrm{kWh} / \mathrm{m}^{3}\right)$ & $(2)\left(\mathrm{kWh} / \mathrm{m}^{3}\right)$ & & & \\
\hline 38 & $\begin{array}{l}98.90 \\
16.40\end{array}$ & $\begin{array}{r}10.14 \\
6.67\end{array}$ & $\begin{array}{l}11.37 \\
17.26\end{array}$ & $\begin{array}{l}17.8 \\
12.7\end{array}$ & . & 0.008 & 0.062 & $\begin{array}{l}38 \text { 年度平均ノズル } 22 \mathrm{~mm} \\
\text { 旬間最高ノズル } 22 \mathrm{~mm}\end{array}$ \\
\hline 39 & $\begin{array}{r}231.35 \\
15.08\end{array}$ & $\begin{array}{r}12.8 \\
8.9\end{array}$ & $\begin{array}{l}7.72 \\
12.3\end{array}$ & $\begin{array}{l}23.0 \\
14.5\end{array}$ & 5.7 & 0.026 & 0.018 & $\begin{array}{l}39 \text { 年度平均ノズル } 18,20,22 \mathrm{~mm} \\
\text { サイクル別最高ノズル } 22 \mathrm{~mm}\end{array}$ \\
\hline 40 & $\begin{array}{r}201.73 \\
120.21 \\
20.20 \\
\end{array}$ & $\begin{array}{l}5.2 \\
3.9\end{array}$ & $\begin{array}{l}18.09 \\
22.7 \\
30.3\end{array}$ & $\begin{array}{l}13.6 \\
12.1\end{array}$ & 3.3 & $\begin{array}{r}0.012 \\
0.020 \\
0\end{array}$ & 0.045 & $\begin{array}{l}40 \text { 年度平均ノズル } 20,22 \mathrm{~mm} \\
\text { ノズル } 22 \mathrm{~mm} \text { の平均 } \\
\text { サイクル別最高ノズル } 22 \mathrm{~mm}\end{array}$ \\
\hline 41 & 491.33 & $\begin{array}{c}10.4 \\
(6.0)\end{array}$ & 19.4 & 16.4 & 5.1 & 0.038 & 0.029 & $\begin{array}{l}41 \text { 年度平均 } \\
\text { 掘さく押流しのみの場合 }\end{array}$ \\
\hline
\end{tabular}

註 5 掘さく能率 $\mathrm{m}^{3} / \mathrm{m}^{3}=$ 水 $/$ 鉱石, $\mathrm{m}^{3} / \mathrm{h}=$ 掘さく量 $/$ 噴射時間

6 電力量 (1) $\mathrm{kWh} / \mathrm{m}^{3}=$ 高圧ポンプの掘さく量当り電力消費量, (2) $\mathrm{kWh} / \mathrm{m}^{3}=$ 輸送ポンプの掘さく量当り電力消費量

中割坑道に打いて運搬にスクレーパを使用したため, パルプ濃度の変動が著しく（４1年11月9日の測定では 1 日平均濃度 $12.5 \%$, 瞬間最高濃度 $42.9 \%$ ） パイプの閉 塞など輸送上の支障を来たしたので, 第 3 図のよ5に口 ータリフィーダを使用し好結果を得た。ポンプ通過方式 で, 最も問題になるポンプの摩耗については，1号機は 輸送鉱石最大粒度 $25 \mathrm{~mm}$, 平均濃度 $6 \%$ で $570 \mathrm{t}$ を輸送 した結果，当初予想しなかうた部分が著しく摩耗し使用 不能となったので別機種により輸送試験を行ない，輸送 鉝石最大粒度 $25 \mathrm{~mm}$ を $223 \mathrm{t} ， 10 \mathrm{~mm}$ を $666 \mathrm{t}, 5 \mathrm{~mm}$ を $15 \mathrm{t}$, 平均濃度 $12 \%$ で合計 $904 \mathrm{t}$ を輸送した結果推定 される部品の消耗費は, 一輸送鉱石 $\mathrm{t}$ あたり159 円となっ た。採掘量に対する輸送時点でのウラン収率は 41 年度 $77 \%, 42$ 年度 $72 \%$ となった。

\section{7.むすび}

以上人形峠型ウラン鉱床の特性を利用した水力採鉱試 験の概要について述へたが, この採鉱法の最大の利点は
（1）掘さく扣よび押流し（切羽運搬）が高能率で行 なわれること。

(2) 選鉱工程が簡略化されること。

などである。設備の不均衡により高能率での連続操業 試験はできなかったが主な項目別の試験も終り，採鉱， 製鍊の一貫操業試験にも成功し，現在原価を試算中であ る。過去数年にわたって開発を進めてきた形峠型ウラ ン鉱床に対する水力採鉱の適用試験は一応初期の目的を 達し完了したが, 開発した採鉣技術は将来の資源開発に さいし活用を図りたい所存である。

\section{謝辞}

終りに本試験の実施にあたり東京大学下村彌太郎教授 をはじめ, 工業技術院資源技術試験所採鉱保安部佐々木 和郎部長ならびに水力採炭研究公の山門技官をはじめ各 技官の方々から懇切な御指導をいただんた。ここに深甚 な感謝を捧汭るものである。

\section{7＼cjkstart排水管など自重による挫屈について（第 4 報）}

$\begin{array}{rrrrr}\text { 東北大学工学部教授 } \cdot \text { 工博 } & \text { 吉 } & \text { 沢 } & \text { 幸 } & \text { 雄 }(\text { 正会員) } \\ \text { 東北大学工学部助教授 } \cdot \text { 工博 } & \text { 川 } & \text { 島 } & \text { 俊 } & \text { 夫(正会員) } \\ \text {. 山形大学教育学部助教授 } & \bigcirc \text { 富 } & \text { 地 } & \text { 信 } & \text { 夫(正会員) }\end{array}$

\section{1.はじめ}

筆者らは, いままで外径 $6 \mathrm{~mm}$, 外径 $8 \mathrm{~mm}$ 抢よび外径 $10 \mathrm{~mm}$ ( んずれる肉厚 $1 \mathrm{~mm}$ ) の鉄パイプを用いて実験し た挫屈長さ $l c r$ 扣上び筆者らの求めた実験式について考 察したが ${ }^{1 ） 2 ｝ \text { ，本報告では前報 }{ }^{3)} て ゙ \text { 示した境界条件のも }$ とで, 外径 $6 \mathrm{~mm}$, 外径 $8 \mathrm{~mm}$ の銅パイプ（鉄の弾性係数の 約半分の值）扣よび銅棒伅ついて実験し，またいままで 全く文献に見られないパイプに水を流した場合について る実験をしたのでその結果につとて併せ報告する。

\section{2. 実験装置および実験方法}

実験装置は従来と同一のもの4）用いたが，水を流す 場合には，供試片受け棒の下部より送水し，しかもコレ ットチャッタで供試片を固定できるような特製の供試片 受け棒を用いた。水は小型摩擦ポンプで送り, バルブで 流量調節を扣こなった。パイプ上端よりの噴出水は, 上 端に設けたバケットに受け，ビニールホースで下方に流 れるようにした。バケットはその下面とパイプ先端が接
触することなく噴出水を受けられ，また噴出水がパイプ にふりかかり，たわみに影響することのないような構造 にした。流速はビニールホースよりの排水量を測定し求 めた。

\section{3. 実験 結果}

銅パイプ技よび銅棒での実験結果を第 1 図に示す。外 径 $6 \mathrm{~mm}$ では長さ $3000 \mathrm{~mm}$ 以上, 外径 $8 \mathrm{~mm}$ では $3700 \mathrm{~mm}$ 以上の試料ではパイプが極めて不安定な状態となり，た わみの測定ば困難であった。図中の破線は外径 $8 \mathrm{~mm}$ の銅 棒の測定結果であるが, 図が複雑になるので夷験点の記 大を省略した。この結果をみれば，やはりパイプ径の大 なるほど，上端のたわみ量 $\delta_{0}$ の急に増加するパイプ長 さ $l_{0}$ は増し, 同じ外径 $8 \mathrm{~mm}$ のパイプと棒では単位長さ 当りの重量の大なる棒の方が大きなたわみ量を示した。

第 1 図の関係を両対数で表示すると第 2 図のよ5にな る。この場合外径 $8 \mathrm{~mm}$ のパイプでは変曲点 ${ }^{4}$ は $l_{0}=2100$ $\mathrm{mm}$ 付近にはっきり見られる。これに対して外径 $6 \mathrm{~mm}$ の パイプでは $l_{0}=1700 \mathrm{~mm}$ 付近にあるらしいが，あまり明

Vol. 84 No. 959 ('68-3) 